Please do not remove this page

RMIT

UNIVERSITY

\title{
Infrastructure planning: in a state of panic?
}

https://researchrepository.rmit.edu.au/esploro/outputs/9921858878701341/filesAndLinks?institution=61RMIT_INST\&index=null

Legacy, C. (2017). Infrastructure planning: in a state of panic? Urban Policy and Research, 35(1), 61-73.

https://doi.org/10.1080/08111146.2016.1235033

Document Version: Accepted Manuscript

Published Version: https://doi.org/10.1080/08111146.2016.1235033

Repository homepage: https://researchrepository.rmit.edu.au

(C) 2016 Editorial Board, Urban Policy and Research

Downloaded On 2023/04/26 19:17:31 +1000 
Thank you for downloading this document from the RMIT Research Repository.

The RMIT Research Repository is an open access database showcasing the research outputs of RMIT University researchers.

RMIT Research Repository: http://researchbank.rmit.edu.au/

\footnotetext{
Citation:

Legacy, C 2017, 'Infrastructure planning: in a state of panic?', Urban Policy and Research, vol. 35, no. 1, pp. 61-73.
}

See this record in the RMIT Research Repository at:

https://researchbank.rmit.edu.au/view/rmit:42837

Version: Accepted Manuscript

Copyright Statement:

(c) 2016 Editorial Board, Urban Policy and Research

Link to Published Version:

http://dx.doi.org/10.1080/08111146.2016.1235033 


\section{Infrastructure planning: in a state of panic?}

\section{Crystal Legacy}

Infrastructure is routinely framed in contemporary urban policy as a vehicle to grow the economy through the creation of jobs. In periods of economic downturn and when ongoing fiscal uncertainty ensues, governments may look to the construction and maintenance of social and public infrastructure such as social housing and public transport. Cities and communities that have endured infrastructure deficits in the past may become the beneficiaries of adjusted national and state-level policy to support economic prosperity through expedient infrastructure implementation programs. Yet in the post-GFC policy environment urban infrastructure has recentred the role of infrastructure in driving urban economic recovery in terms of economic prosperity. Drawing from the state of exception literature, I call on the notion of urgency to explore infrastructure planning as it manifests at the juncture between strategic planning and implementation. This paper will contribute to the critical urban planning literature by examining how infrastructure prioritisation and implementation is shaped through a characterisation of urgency which subverts the relationship between urban infrastructure planning, implementation and planning process.

Key words: Infrastructure, urban governance, urban politics, strategic planning, Canada, Australia 


\section{Introduction}

The collapse of the global financial systems in 2008 spurred countries including Australia and Canada into an exceptional period of infrastructure investment. These two countries along with others were urged by the international community to help stimulate their regional and national economies by creating jobs through infrastructure investment (OECD et al, 2012). The infrastructure stimulus packages that followed embraced significant infrastructure building programs designed to inject capital into waning local markets to save jobs. OECD nations in their efforts to avert global economic calamity designed temporary and targeted infrastructure programs (Sharpe and Watts 2012). Streamlining planning and infrastructure processes created the conditions for the immediate construction of infrastructure (Lovering 2010). For cities in countries such as Canada, Australia, the United States and the United Kingdom suffering from declining federal and state investment including social infrastructure (social and affordable housing) and public infrastructure (public transport), the injection offered access to public funding to support the construction of these two critical forms of urban infrastructure (Milligan and Pinnegar 2010; Stilwell and Primrose 2010; Dethier et al, 2012; Addie, 2013). Yet, the volume of infrastructure built or maintained and the speed at which it was delivered in this period was prefaced upon a direct economic logic purporting that infrastructure construction and maintenance creates jobs allowing cities, regions and nations to avoid recession, while other social and environmental goals, including the creation of more modern, greener and socially just infrastructure remained of secondary concern (Stilwell et al, 2010; Stoney et al, 2012). While this period of investment was exceptional and the swiftness of the delivery of social housing and transport was also exceptional, it was made possible by an urgency politics that not only created the conditions to support expediency but helped to further entrench the fracture between strategic policy and infrastructure planning.

In this paper I call on the conceptual notion of urgency to explore infrastructure planning as it manifests at the juncture between the planning of infrastructure and the construction of 
infrastructure. Evoking the word urgency from the state of exception literature (Agamben 1998, 2014; Ong 2006) I consider how notions of urgency produces an action/response dialectic that serves to suspend and subvert processes in place to help link strategic planning with infrastructure implementation. I use 'urgency' as the conceptual and analytical framework to consider how urgency of infrastructure investment is articulated. Through this exploration I endeavour to contribute to the critical urban planning literature towards a more nuanced exploration of how infrastructure planning has fragmented from the long-term planning dialogues about cities. In doing so, I join O'Neil (2010) in asking, what is infrastructure planning for and what purposes is it serving?

In the sections that follow, I first discuss how the urgency of infrastructure delivery has allowed governments to necessitate amended legislation and subvert decision making processes that truncate and minimise the opportunities for disruption. This will be achieved by thinking about infrastructure delivery in the context of the national and state-based urban economic conditions. This is followed by a review of the Canadian and Australian response to the Global Financial Crisis. Drawing from an extensive analysis of infrastructure and budgetary policy documents from the year 2000 to 2015 and conducting 35 key informant interviews with senior executive and policy officers within the Federal and State/Provincial governments I explore the discourse surrounding these respective infrastructure stimulus programs. Finally the paper concludes by arguing that infrastructure prioritisation and implementation is shaped through a characterisation of urgency which has, and continues to subvert the relationship between urban infrastructure planning, implementation and planning process.

\section{Urgency and infrastructure planning}

The state, as a sovereign and distinct entity, has the power to govern and to use that power decisively, allowing it to mobilise its authority in times of crisis. Agamben (1998, p. 12) conceptualises the state's position relative to the formal processes that support the state as an inclusion/exclusion dualistic relationship, where the state of exception is "actually constituted, in its 
very separateness" to everyday governance and legislative protocol. The state has the authority within the limits of its democratic institutions - to make decisions that extend beyond its mandate, to act in response to crises or threats as they arise. When an emergency is called states may act to suspend or amend commonly accepted practices, to positively direct a particular course of action (Adey et al. 2015). Ong $(2006$, p. 7$)$ goes further by arguing that the "sovereign rule [of the state] involves the exception to create new economic possibilities, spaces, and techniques for governing the population". As this relates to an economic crisis such as the Global Financial Crisis of 2008, it is with the highest orders of governments (Federal, State/Province) that responsibility is re-organised and centralised to steer economic regulation. This might include periodic returns to Keynesian policy which forges a macroeconomic regulation of cities (Hardt and Negri, 2000, p. 242), as was seen in the wake of the Global Financial Crisis in some countries.

A strong theme across the state of exception literature is that the state will exercise its unique position in periods deemed exceptional. In these cases, the exception will sometimes only last temporarily, but during that period there may be a momentary 'foreclosure of the political' to protect governance processes from unwanted disruptions that might manifest in the form of citizen resistance or amount through a change in government (Baptista 2013, p. 50). This departure from due process will be perceived as legitimate, in part because of its temporary nature and its connection to a crisis (Baptista 2013). Ostensibly these processes are short term and will typically cease following the event triggering its creation is either overcome or has concluded. The extent to which these changes are necessary reflect the development of a policy or planning discourse that forges connections between the threat and what is perceived to be in the interest of the 'greater' or 'public good' to respond (Gray et al. 2014). Despite the control of the political, these moments and the responses arising are highly political. Given their political orientation the responses ought to illuminate questions about what is the best course of action and what singular (e.g. economy) and wider (e.g. social and environmental) interests are being (and could be) served by the response. 
Urban planning has had only a cursory engagement with the notion of state of exception, but its usefulness as a normative tool has been applied to descriptions of urban governance and planning as they are each amended and reconstituted over space and time. In one manifestation, the state of exception has been evoked to examine mega event planning and readily applied by urban researchers to explain the role and creation of statutory authorities supporting the planning and development of large-scale urban redevelopment (Grey et al. 2014; Shin, 2012). In these cases the state of exception helped reveal an enduring focus throughout these periods on creating the conditions for market participation and efficiency of infrastructure delivery. Swyngedouw et al. (2002) has criticised the impacts of periods of exception on weakening the integration of planning with wider strategic and urban governance processes and also failing to provide the spaces where critical engagement with the deep-seeded social issues and delivery of long-term social and environmental goals could happen.

Periods where an exceptional response might be warranted and where the expediency of delivery might be necessary, the entrenchment of an economic rationalist logic suggested above is compounded by the state of infrastructure planning in countries particularly in Australia and to a lesser extent in Canada where there has been a growing disconnect between infrastructure project delivery and strategic planning. McFarlane et al. (2008) argues that infrastructure planning could seek to drive processes of city (re-)conceptualisation leading to the development of a strategic vision. This would assume that infrastructure serves a much broader social, environmental and spatial function in cities. While in strategic planning these wider normative goals are often made explicit, as Dodson (2009) has shown there is a fracturing of infrastructure project planning from strategic planning: on a practice-based level, infrastructure planning is deeply disconnected from strategic planning in those cities that lack strong strategic planning that is supported in legislation and through jurisdictional coordination across government entities. Perhaps offering an explanation for the splintered and fractured qualities of infrastructure planning (Graham et al., 2002), O'Neil (2010) describes infrastructure as something that was once largely publicly owned, typical of the 
post-war years where the investment produced multiple economic and social equity externalities, but now sits in contrast to the market-based forms of provisions (O'Neil, 2010, p. 9). The economic focus has always been paramount, as O'Neil shows:

...the orthodox economic literature of the time constructed infrastructure as a key provision inside an economic system - over the top of which economic activity was performed. In other words, infrastructure was seen as a key event necessary to, but not exogenous from, the main (enterprise) realm of the economy. That infrastructure delivered other benefits, such as binding the social and cultural activity of a city, was a bonus uncontested by economists so long as the economic benefits of infrastructure provision were sustained. Infrastructure, then, was vital to the economy and critical to the circumstances in which economy could be successfully performed; just it was crucial to the broader social and cultural life of cities (O'Neil, 2010, p. 7)

However, O'Neil describes a shift in state infrastructure practice away from provider towards a model of procurement, where the attention has focused on economic values. This shift has resulted in government negotiating funding and financing with the private sectors within a context of a government's capacity to generate new revenue introducing an opaque decision making environment that reduces public scrutiny over the project selection process, and the values upon which these decisions are being made (Crain et al. 1995, p. 15; O’Neil, 2010). But as Siemiatycki (2005) shows with the prevalence of the private sector and the power they wield, the private sector has a perverse effect on the selection of projects. This is combined with the ascendency of the private sector's role in infrastructure planning to shape processes of assessment and community consultation with the view to creating the perception of a more certain investment environment to benefit project proponents and to support tendering processes. Haughton and McManus (2012) argue that the quasi-public-private funding landscape this has produced has reshaped how social and 
environmental imperatives are considered in decision making, and the speed at which the implementation of those decisions occur.

In planning there is a clear and direct connection between infrastructure planning and provision to economic activity. Harvey (2012) described infrastructure construction as sitting at the juncture between economic reform and productivity; the urbanisation process that drives demand; and the equitable distribution of public resources to meet demand. This complex arena also encounters citizen engagement and opposition. This is also where infrastructure planning becomes political. Infrastructure planning and delivery attracts contestation, particularly as diverse interest groups try to redirect limited financial resources to support new infrastructure in their respective communities (Legacy and van den Nouwelant 2015); or aim to contest proposed projects (Legacy, 2015). Research into the post-political urban condition (Ranciere 1998; Allmendinger and Haughton 2011; Metzger et al. 2015) reveals the binary that situates institutional spaces, where infrastructure decisions are made, outside and beyond the reach of public deliberation processes. Instead, effort by the political executive to depoliticise infrastructure decision making through the creation of statebased infrastructure agencies, has a direct political connection to enabling governments to deliver infrastructure and to do so efficiently.

The following section turns to the urban infrastructure delivery landscape in two countries that before the stimulus packages of the 2009 were initiated, experienced decades of disinvestment (or troubled implementation) of urban public and social infrastructure: Canada and Australia. In the years since the stimulus packages were tabled by the Canadian and Australian federal governments, both countries have observed further commitments to building urban infrastructure and framing this construction through a narrow economic lens. The following analysis draws on interviews from 35 senior federal and provincial/state policy officials and politicians with a portfolio in either urban transport, housing infrastructure or in treasury. The in-depth semi-structured interviews focused on 
how the urgency of the post-GFC period reshaped the way urban infrastructure is conceived, but also prioritised and delivered in Australian and Canadian cities.

\section{An economic shock and its impact on infrastructure investment in Australia and Canada}

In the immediate aftermath of the Global Financial Crisis (GFC), Canadian and Australian cities were impacted by national policies to stimulate job growth. An immediate injection saw infrastructure delivered in a manner that was timely and could forge an immediate economic impact through the injection of capital funding. In the wake of the global economic threat, the Australian Commonwealth government established the two year $\$ 42$ billion Nation Building and Jobs Plan (NBJP) in 2009-10 (Australian Government 2008) while the Canadian federal government announced in the 2009 Federal Budget the two year Economic Action Plan stimulus package offering $\$ 12$ billion to support infrastructure construction or maintenance. In both countries, stimulus programs positioned urban infrastructure spending on the national agenda for the narrow purpose of creating jobs. Both countries invested in urban infrastructure and both relied on fast-tracked approval processes in their delivery of some projects which could be delivered quickly over a period of two to three years (Government of Canada 2012, p. 323; KPMG 2012, pp. 1-3; Australian Government 2011). For both countries there was an explicit commitment to address this crisis by translating government investment into completed projects to deliver upon the specific objective of incentivising growth in GDP and job creation:

Canada's Economic Action Plan is an important contribution to the global response to the current economic downturn. The world economy is highly globalized. It is only by acting together to boost global economic growth that countries can derive maximum impact from their actions.... Accelerating and expanding the recent historic federal investment in infrastructure with almost $\$ 12$ billion in new infrastructure stimulus funding over two years, so that Canada emerges from this economic crisis with more modern and greener infrastructure (Government of Canada, 2009, p 13). 
The Rudd Government today announced a $\$ 42$ billion Nation Building and Jobs Plan to support jobs and invest in future long term economic growth. This historic long term and targeted Nation Building and Jobs Plan is a further decisive step in the Government's response to the severe global recession. Treasury estimates that today's Nation Building and Jobs Plan will support up to 90,000 jobs in 2008-09 and 2009-10.... Direct investment by the Government in goods and services has significant scope to boost economic growth and productivity and support jobs because it adds directly to demand (Department of Treasury, 2009).

The injection resulted in the scaling up of control to higher orders of government, and also the centralisation of decision-making to state/provincial government ministers. While this shift into the hands of higher tiers of government was not atypical for larger and more complex urban infrastructure projects such as rail and roads, smaller projects such as social housing were rescaled up resulting in the removal of control from local government (see Davison et al. 2013). Acute attention and strategic interest was paid to the rapid implementation of major public investment decisions to create jobs.

In Australia, the scope for investment served a dominant economic imperative, while some commentators believed that it also served other important urban, social and environmental priorities (Stilwell and Primrose 2010). While the latter continues to be the subject of some scholarly debate and ongoing empirical analysis (Ruming 2014; Bennett 2012), the stimulus period delivered tangible urban infrastructure outcomes including $\$ 5.6$ billion towards the creation of 19,700 new social housing stock, $\$ 400$ million towards the repair and maintenance for existing social housing (KPMG, 2012, p 1) and \$2.3 billion to improve road and rail infrastructure (Australian Government, 2011, p 8) with little large-scale community-led politicisation of projects emerging. This is in contrast to the years preceding the stimulus period when infrastructure prioritisation and implementation remained a hotly contested, political and complex process that 
sometimes attracted (community) resistance and dissent (Davison et al, 2013; Davison, 2004). But also, the short political cycles and political opportunism that has come to define Australian and Canadian political culture has also gone some way in embroiling infrastructure into a very political landscape manifesting as pork barrelling and ill-conceived prioritisation of projects purported to be lacking proper third party evaluation and assessment (Terrill, 2016; Iggulden, 2016; Alizadeh, 2015; Curry et al, 2015; Stoney et al, 2012).

Similar to Australia, Canada also embraced stimulus reform that included significant investment into urban infrastructure. Early job numbers indicated that Canada was not immune to recession and government intervention was necessary to avoid a significant rise in unemployment (Campbell, 2009). To respond, the Economic Action Plan stimulus package which offered $\$ 12$ billion to support infrastructure construction and maintenance included an Infrastructure Stimulus Fund worth $\$ 4$ billion to support the construction of 4,000 infrastructure projects across Canada. As every dollar committed by the federal government was matched by the provincial and local governments estimates showed that nearly $\$ 60$ billion in expenditures for eligible projects water, wastewater, transit, roads, culture, parks, trails and community services infrastructure resulted over the two-year period of implementation (Bennett 2012, pp. 190-192). Administered by the national agency Infrastructure Canada, the money was directed towards improving, renewing and rehabilitating existing infrastructure and on the construction of new infrastructure that could be delivered in a period of two years. Combining the impact of the Infrastructure Stimulus Fund with the wider Economic Action Plan, a total of 26,000 projects were completed over two years, creating an estimated 400,000 jobs (Government of Canada 2011).

In the eight years preceding the GFC, the national governments of Canada and Australia announced major infrastructure programs. In Canada significant federal policy milestones including the 2004 New Deal for Cities and Communities, which led to the creation of the Gas Tax, demonstrated a federal commitment to assisting cities with their urban related challenges 
(Turgeon et al. 2013, p. 151). The latter provided $\$ 2$ billion a year to municipalities to support the construction of "environmentally sustainable municipal infrastructure" (Steinberg 2013, p. 227). A national focus on infrastructure would continue into the year 2006 with the announcement of a \$33 billion Building Canada Plan between 2007-2014 (Turgeon et al. 2013, p. 156). But this money would remain under-committed while projects remained under-delivered (Mirza 2007). In contrast to Canada, Australia experienced a succession of budgetary surpluses from 2000 to the announcement of the stimulus programs in 2008-09. These surpluses allowed the Commonwealth Government under the leadership of Prime Minister John Howard to increase spending in areas including social security and welfare, health, education and defence but with rudimentary attention given to social housing (Beer et al, 2007) and an imbalance of spending directed at roads over public transport (Low et al, 2009, p. 49). Yet, the surpluses achieved coupled with the mining boom over this period helped to position the Commonwealth Government in a favourable place to respond to the GFC.

But in light of the federal investment available to infrastructure, a recent history of disinvestment by the Canadian and Australian federal and state/provincial governments in some forms of urban infrastructure coupled with high rates of urbanisation and population growth, and the inequitable distribution of infrastructure investment and prioritisation have contributed to a perception that there is a crisis in the implementation of infrastructure in these two countries: infrastructure investment in some areas of social and public infrastructure had not kept pace (Mirza 2007; Currie et al. 2009; Victorian Auditor General 2013). In Australia, the stimulus programs provided a temporary injection into the infrastructure delivery landscape. It did so by streamlining local planning processes through the introduction of some state based, stimulus focused Acts such as the Nation Building and Jobs Plan Act (State Infrastructure Delivery) Act 2009 that included exemptions to amendments. Whereas, in Canada, there was an explicit commitment to deliver projects in a timely fashion. But communicating to the provinces, municipalities and the private and not-for-profit sectors in Canada that the injection would be temporary (lasting two years) 
and targeted meant that all parties needed to commit to a more efficient means of implementation. This demanding timeline was made possible by altering the processes and governance structures supporting urban infrastructure implementation (Owens et al. 2011) including permanent changes to the Environmental Assessment Act for some projects, which included:

introducing a series of exclusions, thereby eliminating the need for environmental assessments for a wider range of projects...[enabled] through changes to the Exclusion List Regulations under the Canadian Environmental Assessment Act... In order to bring about the changes quickly, the regulations were not released in draft form for public comment before they took effect. As stated in the regulations, the new exclusions were intended to be temporary and were slated to expire on 31 March 2011. Through legislation implementing Budget 2010, these exemptions from environmental assessment requirements became permanent for certain infrastructure programs (Government of Canada, 2010).

The conceptualisation of infrastructure priorities and delivery as urgent has reconstituted the role of the infrastructure implementation process to one of serving national imperatives of growth and job creation. The revised delivery model was described by one Canadian interviewee as a "revolution", describing the level of urgency as commensurate with the commitment to deliver outputs. This investment would be a "once in a generation type investment" (Provincial Government, Senior level Infrastructure Officer, Interviewee 9). The interviewee's suggestion of a 'revolution' reflected the injection of federal funds and how the interjection by the federal government to prioritise infrastructure resulted in the highest order of government establishing a renewed focus on urban infrastructure. It also provided an opportunity to address the growing infrastructure deficit - which in Canada following a 2007 Federation of Canadian Municipality report was worth $\$ 22.8$ billion (Mirza 2007) - growing from a lack of investment and high rates of 
population growth. This period of national intervention and fiscal injection was met by some infrastructure policy officials with great excitement, as one interviewee described below:

It was very exciting. As a public servant, to be working on something that is a high priority for the government means you're in a very dynamic and fast moving work environment. It's very exciting because the things we were working on were taking place in real time. This was from an infrastructure program delivery model that I think we were all fairly familiar with from having worked on previous programs; but redesigning it to meet a very specific goal that was publicly stated and that was being very closely watched and monitored by parliamentarians, by the public, by the parliamentary budget officer. This was very exciting and very challenging. Again, as a public servant when you see that you're working on something that is very real and happening right then and there it's very rewarding (Federal Government, Senior level Infrastructure Office, Interviewee 6).

The concentrated and intense period of investment that defined the GFC period of stimulus contributed to an increased awareness of the strategic importance of urban infrastructure (e.g. to meet the growing infrastructure needs of communities), but at the same time, it also entrenched the economic function that infrastructure plays. One interviewee suggested that "whether you call it cost of living, whether you call it productivity, whether you call it congestion, aspects of infrastructure policy are dinner table conversation because people are frustrated about the experience around it" (Senior Executive, Peak Infrastructure Body, Interviewee 4). Reflecting on the stimulus period, Stoney and Krawchenko (2012, p. 494) report that public engagement and debate about infrastructure at this time was driven by the visibility of the scale of federal investment. This visibility led to questions about the siting and sequencing of infrastructure. Interest was raised even further following the relatively recent creation of a series of infrastructure agencies around Australia. As one senior government official discussed: 
It is fierce. I was talking to someone yesterday who's been very instrumental in convincing governments to create Infrastructure Australia and Infrastructure New South Wales and now the Victorian government's Infrastructure Victoria, etcetera. And he said, "I'm starting to wonder whether we made a terrible mistake." "Because," he said, "what we've managed to do very successfully, and through the creation of these organisations, is really raise the interest in infrastructure, its right up there on the agenda, people talk about it, if you only go back ten years, people didn't know what infrastructure meant and everybody's talking about it these days. Governments have sort of jumped on it, like the Prime Minister's saying, "I want to be the Infrastructure Prime Minister," and government's saying, "We're going to drive the development of infrastructure, we need huge investment, and we're going to be the government who makes that investment." So it's so high profile, which means the politics just get harder and harder" (Federal Senior Executive, Interviewee 3)

The increased exposure brought with it questions about both the strategic and spatial prioritisation of infrastructure and the sequencing of its delivery. Not only was there a departure from strategic planning documents, as reported by Steinberg (2013, p. 229), it was the case in Canada that spending in urban transit for instance was done so with little regard for strategic urban planning. It also continued along the same fractured trajectory that would see infrastructure decisions driving land use decisions, and these decisions would be made outside the more strategic decisions about urban form and spatial transformation, as described by Dodson (2009). Projects were not necessarily being determined by need, or even by a fully formed cost benefit analysis, but as the interview data revealed, projects were being determined by the capacity for individual projects to be delivered within the strict timelines necessary to facilitate growth. Little consideration was given to asking strategic questions about the necessity and appropriateness of the investment. During the course of the stimulus period, the prevailing storyline in Canada and Australia was that urban infrastructure serves an economic utility and to maintain economic strength, construction of infrastructure must 
continue through a steady stream of readied projects that could be managed through statutory infrastructure agencies.

\section{Infrastructure planning in a state of panic}

In the post-GFC period, decision making about infrastructure policy and implementation continued to be framed by very narrow economic parameters surrounding growth creation. There has also been a discursive shift towards the rhetoric of urgency. As one Canadian interviewee suggests, the framing of urgency is connected to the logic of economic rationality - we need this project right now because it will serve an economic purpose.

There has been a shift in the way that infrastructure investments are 'sold'. There is a greater emphasis on the impact that projects have on the economy. Because the projects are so expensive, there is a great focus on the economic benefits. Is this the best investment? Is this the best use of dollars? (Senior Federal Policy Officer, Interviewee 7)

In contrast to Australia, Canada could draw on the national level agency, Infrastructure Canada, which was established prior to the GFC, to administer infrastructure programs. It endeavoured to do so through a succession of programs including the 2007 Building Canada Fund, which pledged \$33 billion between 2007 and 2014 as well as the 2009 Infrastructure Stimulus Fund that dedicated $\$ 4$ billion to new infrastructure (Turgeon et al, 2013, 0144 \& 156; Stoney et al, 2013). This was followed in 2013 with the announcement of the New Building Canada Fund which pledged \$14 billion to fund projects "of national, regional and local significance that promote economic growth, job creation and productivity" (Government of Canada, 2016). The budget included \$4 billion for public transit and \$1.4 billion for affordable housing (Evans, 2016). Whereas in Australia there was sense that Australia was on the 'backfoot' when the crisis hit because there was a lack of shovel ready projects to implement. One interviewee saw this as a 
failure of infrastructure planning at the national level and resulted in Australia being ill prepared for any economic downturn and for an injection of public dollars to support infrastructure delivery.

Well the great irony is that my job was about reinforcing how important it is to think deeply and carefully about what you invest in. And yet at the same time there was this crisis that, "Oh my goodness, we need to spend. What's shovel-ready?" Well, what was evident was that the states and territories hadn't put enough resources into actually planning so that we actually knew what the most important elements of information were and how to take those further to actually design and do business cases for those pieces of infrastructure (Former State Policy Advisory, Victoria, Interviewee 10).

In the absence of a strong institutional landscape that was also actively engaging in evaluating and assessing infrastructure projects, this interviewee argued by stating that it is difficult to think strategically about the infrastructure to build and how to do so in a manner that is quick, when these institutions are absent. In the period leading to 2009, there had been a lack of upfront strategic planning and preparation around infrastructure at the national level in Australia. Instead, and in contrast to Canada, very few projects could be identified as ready for implementation. Now in the post-GFC landscape, Australia has experienced a renewed focus on infrastructure with the establishment of Infrastructure Australia. One of Infrastructure Australia's primary areas of business is strategically auditing nationally significant infrastructure and to establish a priority list and a pipeline of nationally significant works (Infrastructure Australia 2015). As one former state policy advisor lamented, "it's really important to keep a pipeline of big projects going for employment reasons and that's clearly true when construction is 10 per cent of GDP and a lot of that's housing and commercial buildings but having big projects is really important too...particularly... for the economy and for the state and for the state's reputation because these people have a lot of influence" (Former State Policy Advisory, Victoria, Interviewee 10). In conjunction with a need to 
have a collection of 'shovel ready' projects, delivery was also critical. But as described by Stoney and Krawchenko (2012, p. 486), "There were also concerns that the due process normally associated with government programs was being compromised in the rush to begin construction". The following quote by a federal government executive draws a conceptual connection between the need to subvert normal processes to ensure delivery occurs in a way that addresses the broader economic challenge that prompted the investment in the first place.

But in part I think it was in response to a feeling that at a Commonwealth Government level there wasn't enough data to definitely say we know we're investing in the right projects if we have to do it in a very short order. And I think there's been a number of steps between the time of the GFC and now which have been about governments of different persuasions trying to position themselves and future governments to be better able to hand on heart tell the community "We've had to make some quick decisions but we're making them on the basis of pretty good evidence." And I think that's been an intuitive process (Federal Government Executive, Interviewee 6)

Long delivery times were to be avoided to maximise immediate negative economic impact. Interestingly, where there would typically be process-related delays, amendments to legislation and political rhetoric of economic recovery allowed projects to be delivered quicker. The senior federal bureaucrat quoted below surmised that a general level of understanding and acceptance was achieved amongst the different tiers of government leading to an acute understanding that the primary focus of the infrastructure injection was job creation and growth. Little space was given to contemplate project selection and different delivery strategies, nor was it desirable for these projects to be caught in a political debate. Regarding the former, it was understood that upfront strategic consultation work would prepare the project for implementation. As one Canadian senior provincial bureaucrat notes 
below, there is a point when a decision about infrastructure investment and delivery needs to be made.

Provincial governments, municipalities, everybody kind of came together, and when you said this is for a stimulus package, everything else was thrown out the window and you worked on that. It happened at all levels of government. So there was a level of urgency that really helped this (Federal Government, Senior Infrastructure Minister, Interviewee 16).

And for a time, it would seem that designing processes that can make infrastructure delivery more efficient was a warmly received gift by the Canadian federal government. At the height of the GFC, Canadian municipalities were looking for much needed federal dollars to help pay for local infrastructure projects. There was an effort to cut across a number of sectors that were a priority for the Government at the time. A decision had to be made at some point to just get on with doing something to address the downturn. As one advocacy officer for municipalities in Canada shared, "A lot of our members just want results, so they managed the local narrative our city is a sustainable city, our city is an economic city - they manage that" to enable investment and delivery. As another Canadian interviewee remarked, this was the crisis the local municipalities had to observe in order to get delivery: "If there wasn't this crisis where we needed to get stuff done we could be more laissez-faire. But when you stand back and look ...there is an urgency to address the infrastructure, to not only deal with the deficit but the growth that's coming, and if people don't take that seriously you're going to be in a worse and worse condition" (Provincial Transport Agency Executive, Interviewee 22). There was a sense in Canada, particularly, that the expediency and directedness of the stimulus programs was perceived to be acceptable, at least in the short term. Stimulus provided an opportunity to address the pressures brought on by previous disinvestment in infrastructure, helping to address lingering and previously unattained infrastructure targets and meet municipal infrastructure 
objectives. However, a focus on quick delivery and in the context of Canada, an explicit statement that all funds not spent within the specified two-year period would see their funding pulled. The period immediately following the GFC introduced a sense of urgency to the infrastructure case.

\section{Conclusion}

In this paper I argued that there has been a shift in the way urban infrastructure is framed in urban policy discourse, which further extends the period of 'exception' well beyond the period of acute economic crisis experienced in the wake of the GFC. Following an economic shock like the one experienced in 2008, the post GFC economic landscape continues to contain a mix of government stimulus (to address ongoing economic challenges) and alternative financing options (to manage the government deficits that followed) prompting ongoing policy engagement with the resiliency of national and sub-national economic systems (Martin 2012). Framed in contemporary urban policy as a vehicle to both accommodate and spur growth and job creation, in periods of economic downturn and when ongoing fiscal uncertainty ensues, governments continue to look to infrastructure to facilitate economic growth. As a result of the federal investment, municipalities in particular, but also state/provincial governments have become the beneficiaries of adjusted national economic policies that aim to support national economic prosperity through infrastructure implementation programs. For instance, research by Ruming (2014), Davison et al. (2013), Milligan and Pinnegar (2010), Stilwell and Primrose (2010) and Gladstone et al. (2013) have illustrated the positive social and environmental impacts the stimulus period had on constructing critical social and public urban infrastructure. The pace of implementation and the directedness of these processes saw the delivery of new and needed infrastructure, but left wanting were questions of long-term strategic benefit and the re-centring of social and environmental benefits in infrastructure planning.

Now seven years on from the 2008 and 2009 Federal Budgets when infrastructure stimulus was proposed, the economic outlook for Australia and Canada still remains uncertain. In recent years cautionary notes from leading economists posit that immediate shifts in the resources sector and 
manufacturing base pose significant challenges to the Australian and Canadian economies which have become increasingly vulnerable - a departure from the period immediately preceding the GFC when these two economies were celebrated for their shared resiliency (Sorensen et al. 2015; IMF 2010, 2014). In Canada, the recent collapse in oil prices, reduced lending rates and a cautionary economic growth outlook for 2015, saw the Bank of Canada conclude that Canada had entered a recession (Sorsensen and Hutchins 2015). The recent election of the Trudeau government in Canada, combined with his first Federal Budget delivered in 2016, brought forward a political commitment to stimulate the Canadian economy again through quick delivery of infrastructure programs including social housing and public transport projects (Fife, 2016). While in Australia speculation abounds that the Australian economic landscape could also be confronting a period of recession brought about from poor trading of its commodities (Morgan 2015). These anticipated economic challenges have been met with an interest to invest in cities by the Commonwealth government as a way of restructuring the national economy towards innovation (Prime Minister of Australia, 2016). Although the way in which the Canadian and Australian federal government responded to the crisis of 2008 through an investment in infrastructure was historic, I join Dethier and Morrill (2012) to argue that this period has had profound consequences for the way urban infrastructure prioritisation and implementation is generally conceived, changing the role it plays during difficult national economic conditions, and its ongoing role during potential periods of economic restructuring.

Ongoing economic uncertainty experienced by these two countries have herald in a period of discussion about the economic utility of infrastructure. Situating this debate within the literature on state of exception and drawing links to the conceptual notion of 'urgency' raises questions for procedural practices of urban infrastructure delivery and its governance under difficult economic, as well as challenging policy and political circumstances. Adey et al. (2015) write that urgency is the effect of emergency which reframes infrastructure in purely economic terms. But as Nolan (2015) and Featherstone (2015) both argue, the reconceptualisation of urban infrastructure prioritisation and implementation, in particular, as urgent to support economic redevelopment is a political 
decision. The cases presented here are illustrative of how the reconceptualisation has allowed a redesigning of the processes that support infrastructure implementation in 'urgent times'. Describing a process as urgent elevates the significance of the task, but also implies that the action will produce a different and perhaps an even better outcome for cities, as Adey et al. $(2015$, p. 5) write, "emergency as a term is inseparable from faith in action: the promise that some form of action can make a difference to the emergent event" (Adey et al. 2015p. 5). Urban infrastructure in this context occurs as a performing apparatus; it will produce an outcome extending well beyond the piece of infrastructure itself - creating jobs and growth - while specifically investment into social housing during the GFC helped local municipalities work towards their social housing targets. But investing in other forms of infrastructure for the narrow aim of supporting job creation can have devastating consequences for broader social and environmental strategic imperatives, particularly when the money available to fund infrastructure is diverted to other short term priorities creating inequalities in distribution (Collier et al. 2015). The urgency remarked by Adey et al. (2015), in the context of urban infrastructure is about the way urban infrastructure decisions are framed within the broader discourse of urban need and strategic change.

It is difficult to ignore the calls for new and improved public and social infrastructure to support cities as they grow. Thinking strategically about that infrastructure - scheduling delivery, prioritising investment - sit alongside broader strategic questions about how that infrastructure can be used to restructure cities and facilitate a transition towards more equitable and low carbon communities. But as countries like Canada and Australia confront a period of structural readjustment of their dominant economic drivers (post the resources boom), a hopeful view is that this offers an opportunity to position infrastructure - public and social infrastructure - centrally in that transition, as is being seen by recent announcements by the Federal government in Canada. However, by ignoring the framing of infrastructure in terms of 'urgency' and the political dimensions of that framing, infrastructure planning and delivery will continue to be driven by narrow economic 
objectives and remain disconnected from the wider social and environmental goals within urban strategic planning.

\section{Reference List}

Addie, J.-P. D., 2013 Metropolitics in motion: The dynamics of transportation and State reterritialization in the Chicago and Toronto city-regions. Urban Geography, 34(2), 188-217.

Adey, P., Anderson, B. and Graham, S., 2015. Introduction: Governing emergencies: Beyond exceptionality. Theory, Culture \& Society, 32 (2), 3-17.

Agamben, G., 1998. Homo Sacer: Sovereign power and bare life. Stanford: Stanford University Press.

Agamben, G., 2014. What is a destituent power? Environment and Planning D: Society and Space, 32, 65-74.

Alizadeh, T., 2015, 'Telecommunication Infrastructure and Pork Barrel Politics? An Investigation of the National Broadband Network Early Rollout and Voting Behaviour in Australia. State of Australian Cities Conference Proceedings. December 2015. Gold Coast, Australia.

Allmendinger, P. and Haughton, G., 2011. Post-political spatial planning in England: a crisis of consensus? Transactions of the Institute of British Geographers, 89-103.

Australian Government. 2008. Updated Economic and Fiscal Outlook 2008-09 - Part 2: Nation Building and Jobs Plan: Building prosperity for the future and supporting jobs now. Canberra.

Australian Government. 2011. Commonwealth Coordinator-General's Two Year Progress Review to 31 January 2011: Nation Building Economic Stimulus Plan. Canberra.

Baptista, I., 2013. Practices of exception in urban governance: Reconfiguring power inside the State, Urban Studies, 50 (1), 39-54.

Beer, A., Kearins, B., \& Pieters, H. (2007). Housing affordability and planning in Australia: The challenge of policy under Neo-Liberalism. Housing Studies, 22(1), 11-24.

Bennett, S. E., 2012. Federal Infrastructure Program Impacts: Perceptions at the Community Level. In: B. Doern and C. Stoney, eds. How Ottawa Spends - The Harper majority, budget cuts, and the new opposition (2012-2013): Montreal, McGill-Queen's University Press, 190-206.

Campbell, B., 2009. The Global Economic Crisis and its Canadian Dimension. Canadian Centre for Policy Alternatives, Ottawa, Canada.

Collier, S.J. and Lakoff, A., 2015. Vital systems of security: Reflexive biopolitics and the government of emergency. Theory, Culture \& Society, 32(2), 19-51.

Crain, M.W. and Oakley, L.K., 1995. The Politics of Infrastructure. Journal of Law \& Economics, 38, 117. 
Currie, G., Richardson, T., Smyth, P., Vella-Brodrick, D., Hine, J., Lucas, K., ... Stanley, J., 2009. Investigating links between transport disadvantage, social exclusion and well-being in Melbourne Preliminary results. Transport Policy, 16(3), 97-105.

Curry, B., Hannay, C., 2015. 'Government favours infrastructure projects to Conservative ridings'. The Globe and Mail. Available from: http://www.theglobeandmail.com/news/politics/governmentfavours-infrastructure-projects-to-conservative-ridings/article25492064/ [Accessed 29 June 2016]

Davison, G., 2004. Car Wars: How the Car Won our Hearts and Conquered our Cities. Crows Nest, Australia: Allen and Unwin.

Davison, G., Legacy, C., Liu, E., Han, H., Phibbs, P., van den Nouwelant, R., Darcy, M. and Piracha, A., 2013. Understanding and addressing community opposition to affordable housing development. Australian Housing and Urban Research Institute (AHURI), Final Report No. 211.

Department of the Treasury. 2009. \$42 Billion Nation Building and Jobs Plan. Joint media release by Treasurer Wayne Swan with the Prime Minister Kevin Rudd, 3 February. Available at: http://ministers.treasury.gov.au/DisplayDocs.aspx?doc=pressreleases/2009/009.htm\&pagelD=003\& $\underline{\min =w m s \& \text { Year }=\& \text { DocType }=0}$

Dethier, J.J. and Morrill, C., 2012. The Great Recession and the Future of Cities. Policy Research Working Paper 6256, The World Bank.

Dodson, J., 2009. The 'infrastructure turn' in Australian metropolitan spatial planning. International Planning Studies, 14(2), 109-123.

Evans, P., 2016. Ottawa forecasts $\$ 29.4$ B deficit - with lots more red ink to come. CBC News. Accessed June 6 2016: http://www.cbc.ca/news/business/budget-deficit-infrastructure-1.3502940

Featherstone, D., 2015. Thinking the crisis politically: lineages of resistance to neo-liberalism and the politics of the present conjuncture. Space and Polity, 19 (1), 12-30.

Fife, R., 2016. 'Ottawa eyes faster infrastructure spending to revive economy', The Globe and Mail. http://www.theglobeandmail.com/news/politics/ottawa-mulls-short-term-infrastructure-spendingto-revive-economy/article28176196/ [Accessed 29 June 2016]

Gladstone, J., Kennedy Dalseg, S., and Abele, F., 2013. Promises to keep: Federal spending on communications and transportation infrastructure in the territorial north. In C. Stoney and B. Doern, eds. How Ottawa Spends - The Harper Government: Mid-term blues and long-term plans (20132014). Montreal: McGill-Queen's University Press, 159-171.

Graham, S. \& Marvin, S. 2002. Splintering Urbanism: Networked Infrastructures, technological mobilities and the urban condition, London, Routledge.

Gray, N. and Porter, L., 2014. By any means necessary: Urban regeneration and the "State of Exception" in Glasgow's Commonwealth Games 2014. Antipode, 47(2), 380-400.

Government of Canada. 2009. Canada's Economic Action Plan - A first report to Canadians, March 2009. Ottawa: Department of Finance.

Government of Canada. 2010. Report of the Auditor General of Canada to the House of CommonsChapter 1: Canada's Economic Action Plan. Ottawa. Office of the Auditor General of Canada

Government of Canada. 2011. Canada's Economic Action Plan - Year 2: Built to keep our economy growing. A Seventh Report to Canadians. Ottawa: Public Works and Government Services Canada. 
Government of Canada. 2012. Jobs Growth and Long-term Prosperity: Economic Action Plan 2012. Ottawa: Public Works and Government Services Canada.

Government of Canada. 2016. The 2014 New Building Canada Fund: Focusing on economic growth, job creation and productivity. Ottawa: Infrastructure Canada.

Hardt, M. \& Negri, A. 2000. Empire, Cambridge, Harvard University Press.

Harvey, D. 2012. Rebel Cities: From the right to the city to the urban revolution. London: Verso.

Haughton, G. and McManus, P., 2012. Neoliberal Experiments with urban infrastructure: The Cross City Tunnel, Sydney. International Journal of Urban and Regional Research, 36(1), 90-105.

Iggulden, T., 2016. 'Election 2016: Poor governance at the root of infrastructure problem, experts say', $A B C$ News, 28 June 2016. Available from: http://www.abc.net.au/news/2016-06-28/poorgovernance-at-root-of-infrastructure-problem/7549540 [Accessed 29 June].

Infrastructure Australia. 2015. Infrastructure Australia: Our Role [online]. Australian Government. Available from: http://infrastructureaustralia.gov.au/about/role.aspx [Accessed 12 August].

International Monetary Fund. 2010. IMF Survey: Mining boom bodes bright future for Australia [online]. IMF. Available from:

https://www.imf.org/external/pubs/ft/survey/so/2010/car102810a.htm [Accessed 12 August].

International Monetary Fund. 2014. IMF Survey: Australia on path to broader-based growth, says IMF [online]. IMF. Available from:

https://www.imf.org/external/pubs/ft/survey/so/2014/car021214a.htm [Accessed 14 August].

KPMG. 2012. Social Housing Initiative Review. KPMG: Canberra.

Legacy, C., 2015. Transforming transport planning in the postpolitical era. Urban Studies, 1-17. doi:10.1177/0042098015602649

Legacy, C., and van den Nouwelant, R., 2015. Negotiating strategic planning's transitional spaces: the case of 'guerrilla governance' in infrastructure planning. Environment and Planning A, 47, 209-226.

Low, N., and Astle, R., 2009. Path dependence in urban transport: an institutional analysis of urban passenger transport in Melbourne, Australia. Transport Policy, 16(2), 47-58.

Lovering, J., 2010. Will the recession prove to be a turning point in planning and development thinking?. International Planning Studies, 15(3), 227-43.

Martin, R., 2012. Regional economic resilience, hysteresis and recessionary shocks., Journal of Economic Geography, 12(1), 1-32.

McFarlane, C. and Rutherford, J., 2008. Political infrastructure: Governing and experiencing the fabric of the city. International Journal of Urban and Regional Research, 32(2), 363-74.

Metzger, J., Allmendinger, P. and Oosterlynck, S., eds., 2015. Planning Against the Political:

Democratic deficits in European territorial governance. New York: Routledge.

Milligan, V. and Pinnegar, S., 2010. The Comeback of National Housing Policy in Australia: First Reflections. International Journal of Housing Policy, 10(3), 325-344.

Mirza, S., 2007. Danger Ahead: the coming collapse of Canada's municipal infrastructure. Ottawa: Federation of Canadian Municipalities. 
Morgan, E., 2015. Analyst Gerard Minack warns Australian heading for recession. ABC News, 9 June. Available from: http://www.abc.net.au/news/2015-06-08/analyst-minack-warns-australia-headingfor-recession/6529212 [Accessed 12 August]

Nolan, L.J. and Featherstone, D., 2015. Contentious politics in austere times. Geography Compass, 110.

OECD, World Bank and United Nations. 2012. Incorporating Green Growth and Sustainable Development Policies into Structural Reform Agenda. Prepared for the G20 Summit 18-19 June 2012. Available from:

http://www.greengrowthknowledge.org/sites/default/files/downloads/resource/Incorporating GG and sustainable development policies into structural reform agendas OECD.pdf [Accessed 12 August]

O'Neil, P. M. 2010. Infrastructure financing and operation in the contemporary city. Geographical Research, 48, 3-12.

Ong, A., 2006. Neoliberalism as exception: mutations in citizenship and sovereignty. Durham: Duke University Press.

Owens, S. and Cowell, R., 2011. Land and Limits: Interpreting sustainability in the planning process, Second edition. New York: Routledge.

Prime Minister of Australia. 2016. 'Smart cities will grow the innovation economy' Media Release, 29 April 2016.

Ranciere, J., 1998. Dis-agreement: Politics and Philosophy. London: University of Minnesota Press.

Ruming, K., 2014. "It wasn't about public housing, it was about the way it was done": Challenging planning not people in resisting the Nation Building Economic Stimulus Plan, Australia. Journal of Housing and the Built Environment, 29(1), 39-60.

Sharpe, T. and Watts, M., 2012. Policy advice in crisis: How intergovernmental organisations have responded to the GFC. Journal of Australian Political Economy, 69, 103-133.

Shin, H. B. 2012. Unequal cities of spectacle and mega-events in China. Cities, 16, 728-744.

Siemiatycki, M., 2005. The making of a mega project in the neoliberal city. City: Analysis of urban trends, culture, theory, policy, action, 9(1), 67-83

Sorensen, C. and Hutchins, A., 2015. How Canada's economy went from boom to recession so fast: An in-depth look at the perfect storm that pushed Canada into recession. Macleans, 15 July.

Available from: http://www.macleans.ca/economy/economicanalysis/how-canadas-economy-wentfrom-boom-to-recession-so-fast/ [Accessed 14 August]

Steinberg, J. 2013. The policies and politics of federal public transit infrastructure spending. In C. Stoney and B. Doern, eds. How Ottawa Spends - The Harper Government: Mid-term blues and longtern plans (2013-2014). Montreal: McGill-Queen's University Press, 223-235.

Stilwell, F. and Primrose, D., 2010. Economic stimulus and restructuring: Infrastructure, green jobs and spatial impacts. Urban Policy and Research, 28(1), 5-25.

Stoney, C. and Krawchenko, T., 2012. Transparency and accountability in infrastructure stimulus spending: A comparison of Canadian, Australian and U.S. programs. Canadian Public Administration, 55(4), 481-503. 
Stoney, C. \& Doern, B. 2013. The Harper Government: Mid-term blues and long-term plans. In: Stoney, C. \& Doern, B. (eds.) How Ottawa Spends 2013-2014, the Harper Government: Midterm Blues and Long-term Plans. Montreal: McGill-Queens University Press.

Swyngedouw, E., Moulaert, F. and Rodriguez, A., 2002. Neoliberal urbanization in Europe: large-scale development projects and the new urban policy. Antipode, 34(3), 542-577.

Terrill, M., 2016. Election 2016: will the infrastructure promises meet Australia's needs? Grattan Institute, Melbourne.

Turgeon, L. and Hjartarson, J., 2013. Multi-level governance, infrastructure, and the transformation of accountability regimes in Canada. In P. Graefe, J.M. Simmons and L.A. White, eds. Overpromising and underperforming? Understanding and evaluating new intergovernmental accountability regimes. Toronto: University of Toronto Press, 144-165.

Victorian Auditor General. 2013. Developing transport infrastructure and services for population growth areas. Melbourne: Victorian Auditor General. 